\title{
DAMPAK PANDEMI COVID-19 TERHADAP PENDAPATAN PETANI TEMBAKAU DI DESA PALONGAN
}

\author{
Very Andrianingsih ${ }^{1 *}$, Dessy Novitasari Laras Asih ${ }^{2}$ \\ 1)*, 2) Universitas Wiraraja Madura \\ email: veryandrianingsih@ wiraraja.ac.id ${ }^{1{ }^{*}}$, dessynovitasari@ wiraraja.ac.id ${ }^{2)}$
}

\begin{abstract}
ABSTRAK
Adanya pandemic ini berdampak pada beberapa sektor, salah satunya sektor pertanian. Banyak petani yang mengeluh karena mengalami penurunan pendapatan sejak pandemi COVID-19, khususnya petani di Desa Palongan, Kabupaten Sumenep. Tujuan penelitian ini yaitu untuk mengetahui perbedaan pendapatan petani tembakau di Desa Palongan sebelum dan sesudah Covid-19. Peneliti menggunakan metode kuantitafif deskriptif dengan melakukan wawancara kepada petani dan pengisian kuesioner sebagai penunjang untuk mendapatkan data. Metode analisa penelitian ini menggunakan perhitungan biaya usahatani, penerimaan usahatani, serta pendapatan usahatani. Peneliti menggunakan uji hipotesis paired sample t-test untuk mengetahui rata-rata perbedaan pendapatan antara sebelum dan setelah pandemic covid-19.
\end{abstract}

Kata Kunci : Pandemic Covid-19, Pendapatan, Petani

\section{PENDAHULUAN}

Awal tahun 2020, beberapa negara dikejutkan dengan datangnya virus yang memporak-porandakan seluruh sektor kehidupan. Virus tersebut bernama Corona Virus Disease (COVID-19) yang ditemukan pertama kali di Kota Wuhan, China dan kemudian mewabah hingga ke beberapa negara termasuk Indonesia.

Penyebaran virus ini terbilang sangat cepat dan tentunya juga akan menjadi permasalahan pada berbagai sektor. Pemerintah Indonesia dalam merespon pandemic covid-19 ini menerapkan berbagai macam kebijakan. Salah satunya yaitu adanya social distancing yang dimulai awal bulan Maret 2020 (Hadiwardoyo, 2020). Berlakunya kebijakan PSBB ini, dalam beberapa waktu mewajibkan instansi dan sebagian besar industry tidak dapat beroperasi. Kebijakan tersebut dapat mengakibatkan kerugian ekonomi, selain itu akan berimbas pada mata rantai pasokan seperti menghambat produksi barang dan jasa.

Salah satu dampak dari pandemic Covid-19 yaitu pada sektor ekonomi, seperti beberapa instansi yang melakukan PHK terhadap karyawannya, perubahan sikap masyarakat terutama dalam bidang kesehatan, hingga berdampak pada pendapatan masyarakat sehari-hari. Selain itu, pandemi ini juga berdampak pada menyusutnya ruang dan kesempatan kerja.

Di samping itu, dampak lain yang akan terjadi yaitu pada sektor pertanian. Hal ini dapat menghambat pengiriman hasil produksi karena terganggunya aktivitas produksi dan distribusi. Adanya wabah Covid-19 yang memengaruhi terhadap kemampuan usaha dan pendapatannya juga sangat dirasakan oleh petani dan peternak. Sehubungan dengan 
itu, dilakukan identifikasi dengan berbagai simpul kritis terkait sumber daya pertanian pada masa pandemi ini.

Menurut data BPS (2020b), kontribusi sektor pertanian pada struktur pertumbuhan PDB nasional di triwulan II2020 sebesar $15,46 \%$. Di masa pandemic, pertumbuhan sektor pertanian tentu sangat diharapkan untuk kelangsungan produksi pangan di Indonesia. Namun, keadaan ini dinilai cukup sulit bagi warga Indonesia untuk mengembangkan sektor pertanian, termasuk memberdayakan petani sebagai penopang primer sektor ini.

Hasil pertanian merupakan salah satu komponen penunjang yang dapat membangun daya tahan suatu perekonomian, terlebih pada saat terjadi goncangan, gangguan, dan krisis. Beberapa teori ekonomi membuktikan bahwa sukses pengembangan sektor industrialisasi di suatu negara, diiringi dengan perbaikan produktivitas serta pertumbuhan berkelanjutan pada sektor pertanian. Disamping menyuplai kebutuhan pangan, sektor pertanian juga sebagai distributor bahan baku bagi sektor industri dan sebagai pengahasil devisa negara (Ridha, 2017).

Dengan menurunnya angka produksi hasil pertanian di masa pandemi ini, menjadi salah satu faktor berkurangnya pendapatan para petani, baik petani tembakau, jagung, kedelai, dll. Sumenep merupakan Kabupaten di ujung timur pulau Madura. Sebagian besar mata pencaharian masyarakat Sumenep yaitu sebagai petani dan nelayan. Adanya pandemic COVID-19 ini berimbas pada pendapatan petani di Kabupaten Sumenep khususnya di Desa Palongan. Banyak petani yang mengeluh karena sulitnya mendapatkan produk pertanian, selain itu juga dampak yang sangat dirasakan yaitu pendapatan hasil pertanian yang terus menurun. Oleh sebab itu, diperlukan upaya untuk menstabilkan keadaan ini agar terhindar dari krisis ekonomi.

Tujuan penelitian ini ingin mengkaji lebih dalam perihal seberapa besar dampak pandemi COVID-19 pada sektor pertanian dan pendapatan yang diterima petani Desa Palongan.

\section{METODE PENELITIAN}

Jenis penelitian ini yaitu kuantitatif deskriptif. Penelitian ini bertempat di Desa Palongan, Kecamatan Bluto, Kabupaten Sumenep.

Teknik pengumpulan data dilakukan dengan memberikan kuesioner berisi tentang beberapa pertanyaan terkait usahatani yang nantinya akan dijawab oleh responden. Interview atau wawancara dalam penelitian ini juga digunakan yaitu sebagai alat untuk mendukung jawaban dari seluruh responden. Hal ini dilakukan agar hasil dari kuesioner lebih lengkap dan jelas untuk dilakukan analisis pendapatan petani Selain itu observasi awal penelitian dilakukan untuk menggali informasi mendalam mengenai responden petani tembakau di Desa Palongan.

Dalam penelitian ini, semua populasi diambil sebagai sampel. Teknik pengambilan sampel menggunakan nonprobability sampling dengan jenis sampling jenuh. Tercatat 38 responden yang dijadikan sampel dalam penelitian ini.

Metode analisa data yang digunakan dalam penelitian ini yaitu:

\section{1) Analisa Statistik Deskriptif}

Analisa ini digunakan untuk menjawab faktor-faktor yang mempengaruhi pendapatan usahatani tembakau. Variabel yng digunakan dan diteliti dengan analisis yaitu Luas Lahan Petani, Umur Petani, Tingkat Pendidikan Petani, Pengalaman Usahatani. Selanjutnya hasil data dari 
setiap variabel di sajikan dalam bentuk persentase dan mendeskripsikannya.

2) Pehitungan biaya usaha tani tembakau

Biaya usaha tani merupakan biaya yang dikeluarkan selama proses tanam hingga panen. Terdapat 2 biaya usahatani yaitu biaya tetap dan biaya variabel. Biaya tetap dalam usaha tani tembakau seperti sewa lahan dan penyusutan alat usahatani. Sedangkan biaya variabel dalam usaha tani tembakau seperti, benih, pupuk, listrik, tikar,dan tenaga kerja. Akumulasi biaya produksi usahatani menggunakan rumus berikut:

$$
\mathbf{T C}=\mathbf{F C}+\mathrm{VC}
$$

Keterangan:

TC: Total Cost

FC: Fixed Cost

VC:Variabel Cost

3) Perhitungan penerimaan usaha tani tembakau

Total penerimaan usahatani adalah hasil perkalian antara harga per produksi $(\mathrm{P})$ dengan kuantitas panen (Q). Pada usaha tani tembakau, penerimaan yaitu hasil perkalian dari harga jual per produksi dengan jumlah produksi tembakau yang di hasilkan per hektare dalam satu kali musim. Besarnya penerimaan ditentukan dari besarnya produksi usaha tani serta harga jual per produk. Perhitungan penerimaan usahatani menaggunakan rumus berikut:

$$
\mathbf{T R}=\mathbf{P} \times \mathbf{Q}
$$

Keterangan:

TR: Total Revenue

P: Harga per produksi

\section{Q: Kuantitas Panen tembakau}

4) Perhitungan pendapatan usaha tani tembakau

Pendapatan usahatani ialah ukuran laba usahatani yang dihasilkan. Pada usahatani tembakau, pendapatan yaitu selisih antara total revenue dan total cost usahatani pada satu kali musim tanam. Perhitungan pendapatan usahatani sebagai berikut:

$$
\pi=\mathrm{TR}-\mathrm{TC}
$$

Keterangan:

$\pi$ : Pendapatan

TR: Total Revenue

TC: Total Cost

5) Analisa Uji Beda Rata-Rata Usahatani Tembakau (Paired Sampel t-Test)

Rata-rata pendapatan petani di uji menggunakan perhitungan statistic agar mengetahui perbedaan nilai rata-rata pendapatan usahatani tembakau sebelum adanya pandemi covid-19 dengan pendapatan usahatani tembakau setelah covid-19 di Desa Palongan. Dasar pengambilan keputusan berdasarkan probabilitas yang digunakan yaitu $\mathrm{H}_{0}$ diterima apabila nilai signifikansi $>0,05$ sedangkan $\mathrm{H}_{0}$ ditolak apabila nilai signifikansi < 0,05 . Hipotesis pada uji ini sebagai berikut:

$\mathrm{H}_{0}$ : tidak terdapat perbedaan yang signifikan antara rata-rata pendapatan usahatani tembakau sebelum pandemi Covid-19 dengan rata-rata pendapatan setelah pandemi Covid-19.

$\mathrm{H}_{1}$ : terdapat perbedaan yang signifikan antara rata-rata pendapatan usahatani tembakau sebelum pandemi Covid-19 dengan rata-rata pendapatan setelah pandemi Covid-19

\section{HASIL DAN PEMBAHASAN}

Keberhasilan usahatani tembakau di masa pandemi Covid-19 dalam meningkatkan pendapatan petani di Desa 
Palongan ditentukan oleh beberapa faktor dan beberapa karakteristik dari petani (responden). Berdasarkan data hasil yang diperoleh, luas lahan yang dikelola tiap petani berbeda beda. Data luas lahan yang disajikan dalam penelitian ini yaitu menurut penggunaan luas yang ditanami tembakau. Luas lahan tersebut disajikan pada tabel 1 berikut:

\section{Tabel 1: Luas Lahan Usahatani} Tembakau

\begin{tabular}{|c|c|c|c|}
\hline No. & $\begin{array}{c}\text { Luas } \\
\text { Lahan } \\
(\mathbf{m} 2)\end{array}$ & $\begin{array}{c}\text { Frekuensi } \\
\text { (orang) }\end{array}$ & $\begin{array}{c}\text { Persentase } \\
(\mathbf{\%})\end{array}$ \\
\hline 1. & 1000 & 19 & 50,00 \\
\hline 2. & 2000 & 18 & 47,00 \\
\hline 3. & 3000 & 1 & 3,00 \\
\hline 4. & $>4000$ & 0 & 0,00 \\
\hline & Total & $\mathbf{3 8}$ & $\mathbf{1 0 0 , 0 0}$ \\
\hline
\end{tabular}

Sumber: Data Primer Diolah Peneliti

Berdasarkan data dari kuesioner menunjukkan bahwa mayoritas masyarakat petani di Desa Palongan memiliki luas lahan $0,15 \mathrm{Ha}(1500 \mathrm{~m} 2)$ yang tercatat sebanyak 19 orang. Petani dengan luas lahan 0,2 Ha (2000 m2) sebanyak 18 orang, dan petani dengan luas lahan 0,3 Ha (3000 m2) sebanyak 1 orang.

Bekerja pada sektor pertanian, faktor utama yang diperlukan adalah kekuatan fisik. Usia petani menjadi salah satu tolak ukur untuk melihat kekuatan fisik yang dimiliki seseorang. Umur seseorang dibagi menjadi dua golongan, yaitu umur 15-64 tahun termasuk umur produktif, sedangkan umur 64 tahun ke atas merupakan umur non produktif. Klasifikasi umur petani tembakau disajikan dalam tabel 2 berikut:

Tabel 2. Klasifikasi Umur Petani Tembakau

\begin{tabular}{|c|c|c|c|}
\hline No. & $\begin{array}{c}\text { Umur } \\
(\text { Th) }\end{array}$ & $\begin{array}{c}\text { Frekuensi } \\
\text { (orang) }\end{array}$ & $\begin{array}{c}\text { Persentase } \\
(\boldsymbol{\%})\end{array}$ \\
\hline 1. & $15-64$ & 36 & 95,00 \\
\hline 2. & $>64$ & 2 & 5,00 \\
\hline \multicolumn{2}{|c|}{ Total } & $\mathbf{3 8}$ & $\mathbf{1 0 0 , 0 0}$ \\
\hline
\end{tabular}

Sumber: Data Primer Diolah Peneliti
Dapat diketahui bahwa mayoritas responden berada pada golongan umur produktif. Responden dengan umr 15-64 tahun sebanyak 36 orang atau sebesar $95 \%$, sedangkan responden dengan umr lebih dari 64 tahun sebanyak 2 orang atau sebesar $5 \%$.

Selain itu pendidikan juga berpengaruh terhadap pengambilan keputusan seorang petani dalam melakukan pengembangan usahataninya. Petani dengan tingkat pendidikan tinggi akan memiliki pola pikir yang lebih baik, sehingga memungkinkan untuk bertindak lebih rasional dalam mengelola usaha taninya. Klasifikasi tingkat pendidikan petani disajikan pada tabel 3 sebagai berikut.

Tabel 3. Klasifikasi Tingkat Pendidikan Petani Tembakau

\begin{tabular}{|c|c|c|c|}
\hline No & $\begin{array}{c}\text { Tingkat } \\
\text { Pendidikan }\end{array}$ & $\begin{array}{c}\text { Frekuensi } \\
\text { (orang) }\end{array}$ & $\begin{array}{c}\text { Persentase } \\
(\mathbf{\%})\end{array}$ \\
\hline 1. & SD & 23 & 60,00 \\
\hline 2. & SMP & 9 & 24,00 \\
\hline 3. & SMA & 6 & 16,00 \\
\hline & Total & $\mathbf{3 8}$ & $\mathbf{1 0 0 , 0 0}$ \\
\hline
\end{tabular}

Sumber: Data Primer Diolah Peneliti

Berdasarkan tabel di atas menunjukkan bahwa reponden pada tingkat pendidikan SD sebanyak 23 orang atau 60\%, responden pada tingkat pendidikan SMP sebesar 24\%, dan responden dengan tingkat pendidikan SMA sebesar 16\%. Maka dapat disimpulkan bahwa sebagian besar tingkat pendidikan responden pada penelitian ini ini berpendidikan Sekolah Dasar.

Pengalaman usahatani juga menjadi faktor pemicu peningkatan pendapatan petani tembakau. Lamanya berusahatani membuat seorang petani memiliki pengalaman dan pengetahuan di bidang pertanian. Petani yang berpengalaman, tentunya memiliki kapasitas pengelolaan usahatani yang lebih matang dan juga dapat menghasilkan produk pertanian 
dengan kualitas terbaik. Pada tabel 4 disajikan pengalaman usahatani tembakau.

Tabel 4. Pengalaman Usahatani Tembakau

\begin{tabular}{|c|c|c|c|}
\hline No & $\begin{array}{c}\text { Pengalaman } \\
\text { usahatani } \\
\text { (tahun) }\end{array}$ & $\begin{array}{c}\text { Frekuensi } \\
\text { (orang) }\end{array}$ & $\begin{array}{c}\text { Persentase } \\
(\mathbf{\%})\end{array}$ \\
\hline 1. & $5-10$ & 0 & 00,00 \\
\hline 2. & $10-15$ & 16 & 42,00 \\
\hline 3. & $>15$ & 22 & 58,00 \\
\hline & Total & $\mathbf{3 8}$ & $\mathbf{1 0 0 , 0 0}$ \\
\hline
\end{tabular}

Sumber: Data Primer Diolah Peneliti

Pada tabel di atas menunjukkan bahwa tidak ada petani yang mengelola usaha tani kurang dari 10 tahun. Mayoritas responden sudah melakukan usaha tani lebih dari 15 tahun. Hal tersebut menunjukkan bahwa petani tembakau di Desa Palongan sudah sangat berpengalaman dalam mengelola lahan pertanian atau usahataninya agar dapat menghasilkan tembakau dengan kualitas yang bagus dan mempunyai nilai jual yang tinggi.

Dalam mengelola lahan pertanian, setiap orang memiliki cara yang berbedabeda. Terdapat beberapa faktor yang harus dimiliki seorang petani, diantaranya luas lahan, modal, dan kesiapan fisik yang kuat. Mengelola lahan pertanian, membutuhkan biaya yang besar. Produk hasil pertanian dengan kualitas baik didapat jika petani memiliki biaya yang cukup untuk mengelolanya. Pendapatan petani tembakau akan meningkat jika produk tembakau yang dihasilkan memiliki kualitas yang bagus, hal itu agar produk mendapat harga jual tinggi. Berikut beberapa analisis yang dilakukan petani agar mengetahui pendapatan yang diterima dari hasil usaha tani tembakau selama satu kali musim.

\section{Perhitungan Biaya Usahatani Tembakau}

Biaya usahatani merupakan biaya yang dikeluarkan oleh petani tembakau di
Desa Palongan selama satu musim. Biaya tersebut antara lain adalah biaya tetap dan biaya variabel. Biaya yang dikeluarkan oleh setiap petani berbeda-beda, disesuaikan dengan luas lahan yang dikelola. Untk mengetahui akumulasi biaya atau total biaya pada satu kali musim tembakau dengan cara biaya tetap di jumlahkan dengan biaya variabel.

Tabel 5. Rata-rata Total Biaya Usahatani Tembakau di Desa Palongan

\begin{tabular}{|l|c|c|}
\hline \multirow{2}{*}{ Uraian } & \multicolumn{2}{|c|}{ Jumlah } \\
\cline { 2 - 3 } & $\begin{array}{c}\text { Sebelum } \\
\text { Pandemi } \\
\text { Covid-19 } \\
\text { (Rp) }\end{array}$ & $\begin{array}{c}\text { Sesudah } \\
\text { Pandemi } \\
\text { Covid-19 } \\
\text { (Rp) }\end{array}$ \\
\hline Biaya Tetap (FC) & 328.947 & 339.474 \\
\hline Biaya Variabel (VC) & 1.334 .605 & 1.722 .078 \\
\hline Total Biaya (TC) & $\mathbf{1 . 6 6 3 . 5 5 2}$ & $\mathbf{2 . 0 6 1 . 5 5 2}$ \\
\hline
\end{tabular}

Sumber: Data Primer Diolah Peneliti

Berdasarkan hasil tabel di atas, menunjukkan bahwa terjadi kenaikan biaya total pada produksi tembakau di Desa Palongan setelah adanya pandemi covid-19. Biaya sebelum covid-19 sebesar Rp1.663.552, kemudian mengalami kenaikan menjadi Rp2.061.552 setelah adanya covid-19. Hal tersebut dikarenakan adanya pandemi covid-19 membuat harga benih, pupuk, gula, dan lainnya yang di produksi oleh industry naik dan sulit di dapat akibat diterapkannya peraturan pemerintah tentang pembatasan sosial (social distancing).

\section{Perhitungan Penerimaan Usahatani Tembakau}

Penerimaan hasil usahatani tembakau di peroleh dari harga tawar tembakau dikalikan dengan banyaknya hasil produksi yang di dapat. Penerimaan yang di dapat petani tembakau di Desa Palongan berbeda-beda sesuai dengan seberapa banyak hasil yang di peroleh dalam satu kali musim. Penerimaan yang diterima sebelum pandemi dan setelah pandemic disajikan pada tabel berikut: 
Tabel 6. Rata-rata Penerimaan Usahatani Tembakau di Desa Palongan

\begin{tabular}{|l|c|c|}
\hline \multirow{2}{*}{ Uraian } & \multicolumn{2}{|c|}{ Jumlah } \\
\cline { 2 - 3 } & $\begin{array}{c}\text { Sebelum } \\
\text { Pandemi } \\
\text { Covid-19 }\end{array}$ & $\begin{array}{c}\text { Sesudah } \\
\text { Pandemi } \\
\text { Covid-19 }\end{array}$ \\
\hline Hasil Produksi & $137,45 \mathrm{~kg}$ & $150,73 \mathrm{~kg}$ \\
\hline Harga & Rp44.000 & Rp24.000 \\
\hline Penerimaan & Rp6.047.800 & Rp3.617.520 \\
\hline
\end{tabular}

Sumber: Data Primer Diolah Peneliti

Berdasarkan hasil tabel di atas, menunjukkan bahwa penerimaan responden dari usahatani tembakau menurun setelah pandemic Covid-19. Sebelum pandemic Covid-19, rata-rata penerimaan petani tembakau sebesar Rp6.047.800, tetapi setelah pandemi Covid-19 penerimaan petani tembakau menurun menjadi Rp3.617.520. Hal tersebut terjadi karena sebagian besar petani mengurangi jumlah tanamnya. Selain itu sulitnya pendristribusian produk tani tembakau yang diakibatkan banyak perusahaan rokok membatasi aktivitas sejak diterapkannya pembatasan sosial (social distancing).

\section{Perhitungan Pendapatan Usahatani Tembakau}

Pendapatan petani tembakau di peroleh dari deviasi antara penerimaan hasil produksi serta total cost yang dikeluarkan selama aktivitas mengelola tani tembakau yang berlangsung satu musim tanam. Pendapatan yang diperoleh petani tembakau disajikan pada tabel berikut:

Tabel 7. Rata-rata Pendapatan Usahatani Tembakau di Desa Palongan

\begin{tabular}{|l|c|c|}
\hline \multirow{2}{*}{ Uraian } & \multicolumn{2}{|c|}{ Jumlah } \\
\cline { 2 - 3 } & $\begin{array}{c}\text { Sebelum } \\
\text { Pandemi } \\
\text { Covid-19 } \\
\text { (Rp) }\end{array}$ & $\begin{array}{c}\text { Sesudah } \\
\text { Pandemi } \\
\text { Covid-19 } \\
\text { (Rp) }\end{array}$ \\
\hline Penerimaan & 6.047 .800 & 3.617 .520 \\
\hline Total Biaya & 1.663 .552 & 2.061 .552 \\
\hline Pendapatan & $\mathbf{4 . 3 8 4 . 2 4 8}$ & $\mathbf{1 . 5 5 5 . 9 6 8}$ \\
\hline
\end{tabular}

Sumber: Data Primer Diolah Peneliti
Hasil perhitungan di atas menunjukkan bahwa terjadi penurunan pendapatan petani tembakau di Desa. Sebelum pandemi Covid-19 pendapatan petani sebesar Rp4.384.248, namun setelah pandemi Covid-19 menurun menjadi Rp1.555.968. Hal tersebut dikarenakan menurunnya harga jual tembakau, sedangkan biaya tanam tembakau terus mengalami kenaikan semenjak pandemi Covid-19. Akibatnya banyak petani yang mengalami kerugian pada hasil produksi tanam mereka.

\section{Analisa Uji Beda Rata-Rata Pendapatan Petani Tembakau}

Tujuan dilakukannya analisis ini yaitu untuk mengetahui secara statistik apakah terjadi perbedaan pendapatan petani tembakau pada saat sebelum pandemi Covid-19 dan setelah pandemi Covid-19. Taraf signifikansi yang digunakan dalam pengujian ini yaitu $\alpha=$ $5 \%$ atau $\alpha=0,05$. Hasil pengujian disajikan pada tabel 8 berikut:

\section{Tabel 8. Hasil Uji Beda Rata-rata}

\section{Pendapatan Usahatani Tembakau di} Desa Palongan

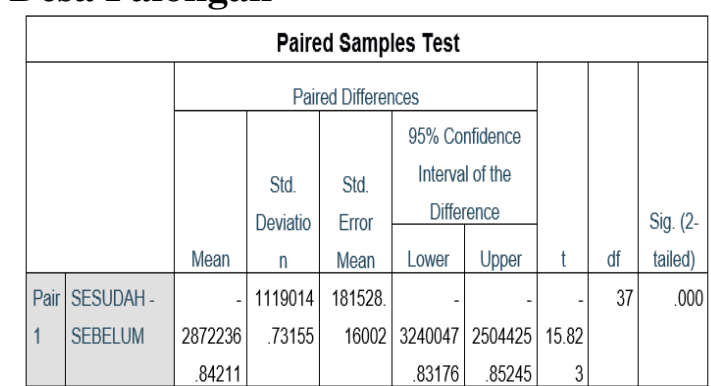

Sumber: Data Hasil SPSS 25

Berdasarkan hasil tabel di atas menunjukkan uji statistik dari pendapatan sebelum pandemi Covid-19 dan setelah pandemi Covid-19 dengan mengacu pada hasil uji paired sample t-Test dengan nilai Signifikansi sebesar 0,000 < 0,05. Dengan demikian $\mathrm{H}_{1}$ diterima, artinya terdapat perbedaan yang signifikan antara rata-rata pendapatan petani tembakau sebelum 
pandemi Covid-19 dan setelah pandemi Covid-19 di Desa Palongan.

Dari hasil data yang diperoleh di lapangan, biaya usaha tani tembakau di Desa Palongan mengalami kenaikan yang disebabkan sulitnya mendapatkan kebutuhan tani tembakau seperti pupuk. Hal tersebut terjadi semenjak diterapkannya pembatasan sosial yang merupakan peraturan pemerintah selama pandemi Covid-19.

Selain itu, pembatasan sosial ini membuat beberapa perusahaan membatasi aktivitas fisik bahkan terpaksa di tutup untuk sementara waktu, seperti perusahaan rokok, industri dan lainnya. Dampaknya terhadap petani yaitu menurunnya harga jual tembakau yang mengakibatkan penerimaan petani menurun.

Sebelum pandemi Covid-19, petani di Desa Palongan mendapat keuntungan yang cukup besar, namun setelah adanya pandemi Covid-19 banyak petani yang mengeluh dikarenakan hasil taninya mengalami penurunan pendapatan.

Hasil statistik juga menunjukkan adanya perbedaan antara rata-rata pendapatan petani tembakau sebelum pandemic Covid-19 dan setelah adanya pandemic Covid-19. Hal tersebut dikarenakan penyaluran logistik pertanian yang terganggu dan membuat para petani kesulitan untuk menjual hasil produksi tani tembakau mereka. Namun meski permintaan akan tembakau menurun, petani tembakau tetap melakukan produksi untuk menunjang keberlangsungan hidupnya.

Hal ini sejalan dengan penelitian Gita dan Fani (2020) yang menyatakan bahwa terjadi perbedaan rata-rata pendapatan petani kelapa sawit sebelum pandemic dan setelah pandemic di Kabupaten Padang Lawas Utara. Penelitian ini di dukung oleh penelitian Fremar, et. al. (2016) yang menyatakan bahwa terdapat perbedaan pendapatan pada usahatani sawah dalam 2 musim panen yang dipengaruhi oleh iklim, harga jual dan biaya.

\section{KESIMPULAN}

Biaya usahatani tembakau sejak pandemi mengalami kenaikan, sedangkan hasil produksi mengalami penurunan yang menyebabkan penerimaan usahatani juga menurun. Maka dari itu pendapatan petani tembakau desa palongan, sejak pandemi covid-19 mengalami penurunan sekitar $40 \%$ dari pendapatan sebelum pandemi. Hal tersebut terjadi sejak diterapkannya social distancing yang menghambat aktivitas masyarakat serta menutup beberapa instansi. Hasil uji statistik juga menunjukkan adanya perbedaan yang signifikan antara rata-rata pendapatan petani tembakau sebelum pandemic Covid-19 dan setelah pandemic Covid-19 di Desa Palongan.

\section{DAFTAR PUSTAKA}

BPS. (2011). "Survei Angkatan Kerja Nasional".'Yogyakarta: Badan Pusat Statistik.

BPS. 2020b. Berita Resmi Statistik No 64/08/Th.Xxii, 5Agustus 2020. Jakarta (Id): Badan Pusat Statistik.

Deviani, Fadilla, et. al (2019) Analisis Faktor-Faktor Yang Mempengaruhi Produksi Usahatani Buncis Di Gabungan Kelompok Tani Lembang Agri Kabupaten Bandung Barat. Jurnal Sosial Ekonomi Dan Kebijakan Pertanian, 3(2): 165-173

Hadiwardoyo, W. (2020). "Kerugian Ekonomi Nasional Akibat Pandemi Covid-19", Journal of Business \& Entrepreneurship, 2(2): 83-92. 
Hamdi Sari Maryoni (2016). "Pengaruh Luas Lahan Pertanian Dan Biayapemeliharaan Terhadap Pendapatan Petani(Studi Kasus Desa Kepenuhan Raya)". Jurnal Ilmiah Cano Ekonomosvol. 5 No. 1 :41-48

Hidayati, Iis W. N (2017). "Analisis Pengaruh Luas Lahan, Jumlah Produksi, Dan Biaya Produksi Terhadap Pendapatan Petani Padi Di Kecamatan Delanggu Kabupaten Klaten (Studi Kasus Di Desa Sribit).’E-Jurnal Ep Unud 2(5): 117.

Noviana,Githa, Ardiani F. (2020). Analisis Pendapatan Petani Kelapa Sawit Sebelum Dan Selama Covid19 (Studi Kasus:Kabupaten Padang LawasUtara).Mediagro,Vol.16(2):18

Oktavia, A. Dkk (2017).”Analisis Produktivitas Tenaga Kerja Sektor Pertanian Di Sumatera".Jurnal Paradigma Ekonomika, Vol. 12. No. $2: 49-56$

Ridha, A (2017). “Analisis Faktor-Faktor Yang Mempengaruhi Pendapatan
Petani Di Kecamatan Nurussalam Aceh Timur". Jurnal Samudra Ekonomika, Vol. 1 (2) :165-173

Sarni, Sidayat, M. (2020). "Dampak Pandemi Covid 19 Terhadap Pendapatan Petani Sayuran Di Kota Ternate". Prosiding Seminar Nasional Agribisnis. Hal: 144-148

Sugiyono (2016). Metode Penelitian Manajemen. Bandung:Alfabeta

Welang, Fremar Refel, et. al. (2016). "Analisis Pendapatan Usahatani Padi Sawah Berdasarkan Musim Panen Di Kelurahan Taratara Satu Kecamatan Tomohon Barat Kota Tomohon". Jurnal AgriSosioEkonomi Unsrat, Vol. 12(2A) :107 - 124

Widarma, Gede, Nyoman D.S. (2019). Factors of Influencing Household Production and Welfare of Corn Farmers: Gerokgak District, Buleleng Regency. International Research Journal of Management, IT \& Social Sciences, Vol. 6 (1): 103-112 